\title{
탄자니아 국별평가 보고서
}

대외경제정책연구원

\section{I. 탄자니아 개발 환경 분석}

\section{1. 정치 · 경제적 여건}

탄자니아는 1964년 본토 탕가니카와 섬나라인 잔지바르의 합병으로 이루어진 연방 합중국으로, 1986년부터 시장경제체제를 적극적으로 도입하면서 다당제 민주주의를 표방하고 있다. 1967년 Arusha 선언 이후 사회주의 경제개발 계획을 추진해왔으나, 취약한 경제구조, 부족한 투자재원 등 으로 인해 실패하고 1986년부터 시장경제체제를 본격적으로 도입하였다. 탄자니아 경제는 농업에 의존하는 과잉노동경제(Labor Surplus Economy)로서 GDP의 절반이 농업분야 생산에 의존하는 최빈개도국이다.

2000년부터 빈곤감소전략(Poverty Reduction Strategy)을 실시하고, IMF는 빈곤감소 · 성장융자 (Poverty reduction and growth facilities) 등을 지원하여 지속적인 구조조정 노력을 강화하고 있 다. 선정(good governance)은 1995년부터 탄자니아 정부가 경제발전을 위한 최우선 과제로써, 탄 자니아 정부는 이를 위해 거버넌스 제고를 전담하는 대통령 직속 사무국 신설, 인권위원회 설립, 효 과적 징세관리를 위한 국세청 설립, '반관(半官) 부문 개혁 프로그램' 운영 등을 시행하고 있다.

2000년 MDG 선언 이후, 의무교육인 초등학교의 등록률은 2005년에 91\%까지 상승하였지만, 중· 고등교육을 받는 청소년의 비중은 여전히 낮으며 보건 및 의료시설 역시 낙후되어 높은 경제성 장률과 정정 안정에도 불구하고 지방 소도시와 농촌의 주민들은 경제성장의 혜택을 전혀 누리지 못 하고 있으며 특히 빈곤층이 집중된 지방과 농촌에 식수공급, 전력공급 등이 원활히 이루어지지 않 고 있다. 또한, 지속적인 구조개혁과 경제성장 노력에도 불구하고 농업(GDP의 $45 \%)$ 에 의존한 취 약한 경제구조, 만성적인 경상수지 적자, 고채무빈곤국(Highly Indebted Poor Country, HIPC)으 로서 원조에 대한 높은 재정의존도 등은 경제의 주요 위협요인으로 작용하고 있다. 


\section{2. 개발정책 및 원조체제}

\section{1) 탄자니아 개발 계획}

탄자니아의 개발계획은 장기 개발계획인 Vision 2025와 National Poverty Eradication Strategy(NPES), 중기 개발계획인 빈곤감소 전략(National Strategy for Growth and Reduction of Poverty, NSGRP)으로 구분된다.

\section{〈그림 1〉 탄자니아/잔지바르 개발계획}
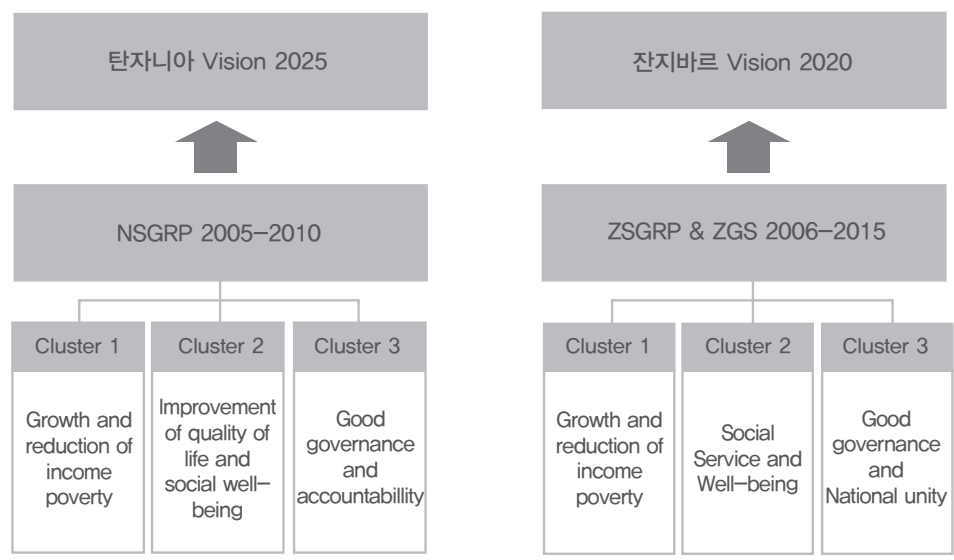

자료: NSGRP, ZSZRP 참조 필자작성

(1) Vision 2025/Vision 2020

‘탄자니아 Vision 2025’는 2025년 최빈국 졸업을 목표로 한 중장기 국가 개발 전략 및 가이드라인 이다. 이 전략은 (1) 삶의 질 향상, (2) 거버넌스 제고와 법치체제 구축, (3) 경쟁력 확보 등을 주요 골 자로 한다.

잔지바르의 장기 개발계획인 Vision 2020은 2020년까지 도시 및 농촌의 절대빈곤층 퇴치를 목표 로 하며 (1) 경제 구조 다각화 및 경쟁력 강화, (2) 경제개발환경 구축, (3) 사회구조 개선, (4) 바람직 한 거버넌스 구축, (5) 평화와 정정안정 등을 주요 골자로 한다.

(2) 탄자니아 빈곤감소전략 $(\mathrm{NSGRP})^{1}$

NSGRP는 기존의 ‘Vision 2025’를 발전시킨 중기 발전계획으로 2005년부터 2010년까지 5년간의

1) 탄자니아 빈곤감소전략(NSGRP)은 스와힐리어로 MKUKUTA임. 
경제개발 및 빈곤 퇴치 전략이다. 이 전략은 (1) 성장 및 빈곤감소, (2) 삶의 질 및 복지수준 향상, (3) 거버넌스 제고 및 책임성 증진을 3대 목표(Cluster)로 한다.

‘Cluster 1. 성장 및 빈곤감소’는 탄자니아는 안정된 경제성장세에도 불구하고 식량생산이 2005 년에 비해 오히려 감소하였고, 빈곤선 이하 인구비중도 크게 줄지 않아, 양질의 경제성장을 위한 노 력이 요구된다. 'Cluster 2. 삶의 질 및 복지수준 향상’의 지표는 초등학교 등록률은 크게 높아지고 식수 접근율과 위생시설 접근율도 개선되었으나, 아직까지 영 - 유아사망률이 크게 높은 것으로 나 타났다. 'Cluster 3. 거버넌스와 책임성' 부문의 부패지수를 살펴보면, 탄자니아의 부패 정도는 크 게 개선되지 못하는 것으로 나타났다.

잔지바르의 중장기 개발계획은 빈곤감소전략(Zanzibar Strategy for Growth and Reduction of Poverty 2007) 과 잔지바르 경제발전전략(Zanzibar Growth Strategy 2006-2015)으로 구성된 다. 이 계획은 (1) 성장 및 빈곤감소, (2) 삶의 질 및 복지수준 향상, (3) 거버넌스 제고 및 단합 등을 3대 목표(Cluster)로 한다.

\section{2) 부문별 개발수요}

가. 농업 및 농촌개발

탄자니아는 농업에 GDP의 $45 \%$, 수출소득의 $60 \%$ 를 의존하고 있지만, 농업부문은 낙후한 상태이 다. 농업기술 부재로 토지 및 노동 생산성이 낮고, 관개시설이 열악하며, 인프라가 부족하여 시장 접근성도 매우 낮다. 따라서 선진 농업기술 증진, 농기계의 현대화, 관개시설 보수, 전력 및 도로 보수 등이 필요한 상황이다.

\section{나. 교육}

탄자니아는 전문기술을 가진 노동력이 매우 부족한 상황인데, 이는 외국기업들이 탄자니아에 대한 투자를 망설이게 하는 주요한 이유이다. 이에 Vision 2025에서는 1대 목표인 높은 삶의 질에 수준 높은 교육을 포함하고 있으며, NSGRP에서도 ‘초중등교육 향상 및 고등, 기술직업훈련 확대’를 목 표로 명시하였다.

$$
\text { 다. 보건 · 의료 }
$$

2) 잔지바르 빈곤감소전략은 스와힐리어로 MKUZA임. 
현재 탄자니아는 보건 · 의료 시설의 절대 부족으로 HIV/AIDS, 수인성 질환, 말라리아 등 질병으 로 인해 영유아 및 산모 사망률이 높은 수준이다. 질병 치료 및 예방에 대한 교육, 의료 시설 확충, 살충제와 모기장 등 예방도구 보급, 전문 보건인 양성 등 보건 · 의료 부문에 대한 개발 수요가 높다.

라. 거버넌스

과거 사회주의 체제의 유산인 관료주의, 공무원들의 역량부족, 정책 연구 부족 등은 탄자니아의 거 버넌스를 위협하는 요인이다. 이에 따라 정책수립, 정책조정, 정책실행 시 효율성을 높이는 행정제 도 개선, 공무원들의 역량 강화를 위한 교육, 정책 연구 강화 등이 탄자니아 거버넌스 개선을 위해 필요하다. 탄자니아 거버넌스 역량 강화와 공공 부문 개혁에는 미국과 영국이 가장 활발한 지원을 하고 있고, 세계은행은 Public Sector Reform Program, Local Government Support Program 등을 통해 지원하고 있다.

마. 인프라

탄자니아의 인프라 시설은 매우 열악하여 시장 및 고용 창출과 무역을 확대하는데 제약을 준다. 특 히 탄자니아 내에서는 통신시설의 부재로 인해 지방간의 의사소통이 원활히 이루어지지 않는 경우 가 많다. 이를 개선하기 위해 탄자니아 정부는 철도, 항만, 공항 도로 네트워크가 개선을 위한 프로 젝트, 이동통신망 확대 프로젝트 등을 계획 중이다.

\section{3) 개발원조체제}

(1) 탄자니아의 수원체제

탄자니아 재무부(Ministry of Finance)는 탄자니아로 유입되는 원조를 총괄적으로 관리하고 있다. 재무부는 공여국 - 공여기관과 협의하여 원조 규모와 원조 방법을 결정하는데, 이때 외국의 원조가 자국의 국가경제개발계획(Vision 2025, NSGRP)의 정책 방향과 일치하도록 조정한다.

일반재정지원 원조 운영의 투명성과 효율성을 높이기 위한 노력의 일환으로 탄자니아 정부는 정부 재정의 계획에서부터 평가까지 (1) 계획: 3년 단위의 중기 정부지출계획(MTEF) (2) 집행: 공공재정 관리체계(PFM) (3) 평가: 공공지출평가(Public Expenditure Review, PER)의 프로세스를 따른다. 


\section{〈표 1〉탄자니아의 행정 및 재정 개혁 프로그램}

\begin{tabular}{|c|c|c|}
\hline 프로그램 & 시기 & 주요 내용 \\
\hline $\begin{array}{l}\text { 공공재정관리개혁 } \\
\text { (PFMRP) }\end{array}$ & 1997- & $\begin{array}{l}\text { - 중기정부지출계획(MTEF)을 도입 } \\
\text { - 공정한 평가를 위한 PER 도입 } \\
\text { - 투명하고 효율적인 정부지출 관리를 위해 중앙 지출 관리 시스템 } \\
\text { (Centralised Payment System) 도입 } \\
\text { - 전산 시스템인 통합관리시스템 IFMS 도입 } \\
\text { - 공여국은 Basket Fund 형태로 지원 }\end{array}$ \\
\hline $\begin{array}{c}\text { 공공서비스 개혁 프로그램 } \\
\text { (PSRP) }\end{array}$ & $\begin{array}{c}2000 \\
- \\
2011\end{array}$ & $\begin{array}{l}\text { - 공무원 봉급체계 개선 } \\
\text { - 공기업 매각을 통한 공공부문 규모 축소 } \\
\text { - Performance monitoring System 도입, 감시기능 강화 } \\
\text { - 지방정부의 역할 및 권한 강화 }\end{array}$ \\
\hline $\begin{array}{c}\text { 지방행정 개혁프로그램 } \\
\text { (LGRP) }\end{array}$ & $2000-$ & $\begin{array}{l}\text { - 지방 정부의 서비스의 접근성 강화 } \\
\text { - 정기 예산 및 개발원조금에 관한 지방정부의 권한 강화 } \\
- \text { 지방정부 공무원의 능력 개발 } \\
-11 \text { 개 공여국이 지방정부개혁을 위한 Basket Fund 지원 }\end{array}$ \\
\hline $\begin{array}{c}\text { 법 부문 개혁프로그램 } \\
\text { (LSRP) }\end{array}$ & $2000-$ & $\begin{array}{l}\text { - 법 관련 공공서비스의 접근성 강화 } \\
\text { - 법 관련 공무원의 능력 개발 }\end{array}$ \\
\hline $\begin{array}{c}\text { 부패방지 전략 및 행동계획 } \\
\text { (NACSAP) }\end{array}$ & $2000-$ & $\begin{array}{l}\text { - 각 부처 및 지방정부의 반부패 Action plan 수립 } \\
\text { - 총리직속의 Good Governance Coordination Unit 신설 } \\
\text { - Public Procurement Act, Public Finance Act 등이 도입되어 공공부문 재 } \\
\text { 정관리의 투명성 강화 }\end{array}$ \\
\hline
\end{tabular}

자료: Kiragu, Kithinki(2005). Tanzania: A case study in comprehensive and programmatic approaches to capacity building. Ministry of Finance(2006), Medium term Expenditure framework cluster-wide strategy. 등 참조.

(2) 공여국의 협력체계

탄자니아 내 원조공여국그룹(Development Partner's Group, 이하 DPG) ${ }^{3)}$ 이 주축이 되어 원조 공여국 간의 원조 협력 및 공여국-탄자니아 정부와의 협력을 주도한다. 탄자니아 정부와 $\mathrm{DPG}$ 는 2006년 12월에 ‘2006 2010년 중기 공동지원전략(Joint Assistance Strategy for Tanzania, 이 하 JAST)'을 수립하여, 주인의식 강화, 공여국간 조화 등 원조효과성 제고를 적극적으로 추진해 오 고 있다.

최근 공여국간 상호 협력 및 업무조정을 위한 역할분담(Division of Labor) 움직임이 강해짐에 따 라, 공여국들은 탄자니아의 경제개발계획이 정한 3개 클러스터를 세분하여 11개 Working Group 을 형성하고 자국이 비교우위가 있는 부문에 Lead, Active, Delegate 형태로 참여하고 있다.

(3) 모니터링 체계

3) DPG 회원국은 벨기에, 캐나다, 덴마크, EC, 핀란드, 프랑스, 독일, 아일랜드, 이태리, 일본, 한국, 네덜란드, 노르웨이, 스 페인, 스웨덴, 스위스, 영국, 미국, UN, 아프리카 개발은행, IMF, 세계은행 등임. 
탄자니아 정부는 일반재정지원 원조를 모니터링 하는 'NSGRP Monitoring System'을 설립하여 운영 중이다. 이 시스템은 탄자니아 빈곤 상황, 거시지표 등의 지표를 설정하여 목표를 세우고, 지 표의 달성 정도에 따라 NSGRP와 공여국의 원조효과를 측정한다. 공여국들은 Public expenditure tracking System을 통해 일반재정지원 형태로 지원한 원조의 지출 금액과 지출 분야 등을 모니터 링 하며, JAST는 'JAST Monitoring Framework'를 통해 탄자니아의 빈곤상황과 원조 효율성 관 련 지표를 설정 - 평가한다. 이외에 독립감시기구(Independent Monitoring Group)를 두어 원조 수행의 효율성 등을 3 년 주기로 감독하도록 하고 있다.

(4) 탄자니아의 원조 수행 체계 평가: 파리선언 지표 활용

'2008 파리선언 이행평가보고서(Evaluation on the Implementation of the Paris Declaration)' 에 따르면 탄자니아는 수원국의 주인의식, 원조 성과 관리, 상호책임 등 부문에서 괄목할 만한 성과 를 보이고 있다.

〈표 2〉 탄자니아의 파리선언 이행 현황

\begin{tabular}{|c|c|c|c|}
\hline 목표 & 2007년 평가 & 개선점 & 개선방안 \\
\hline $\begin{array}{l}\text { 주인의식 } \\
\text { (ownership) }\end{array}$ & 달성 & $\begin{array}{l}\text { 지방정부의 주인의식 } \\
\text { 및 원조역량 부족 }\end{array}$ & $\begin{array}{l}\text { 수원국의 주인의식이 중앙정부에서 } \\
\text { 지방정부까지 확산되어야 함. }\end{array}$ \\
\hline $\begin{array}{c}\text { 공여국 원조와 수원국 } \\
\text { 개발전략의 일치(alignment) }\end{array}$ & 보통 & $\begin{array}{l}\text { 원조집행 절차에서 수원국 } \\
\text { 과 개발전략 일치 부족 }\end{array}$ & $\begin{array}{l}\text { 국가재정기획시스템을 } \\
\text { 활용하여 원조 집행 시에도 탄자니아 } \\
\text { 개발전략 반영 }\end{array}$ \\
\hline 원조 공여국간 조화(harmonization) & 보통 & 공동 현지조사단 부재 & $\begin{array}{l}\text { 공여국간 공동 목표 설정 } \\
\text { 및 공동 프로젝트 운영 }\end{array}$ \\
\hline $\begin{array}{c}\text { 성과 중심의 관리 } \\
\text { (managing for results) }\end{array}$ & 달성 & 최신 원조 통계 부족 & 통계 구축 \\
\hline $\begin{array}{c}\text { 상호책임 } \\
\text { (mutual accountability) }\end{array}$ & 달성 & 시민사회 참여 부족 & JAST에 대한 중간 평가 실시 \\
\hline
\end{tabular}

자료: 원조 효과성 제고를 위한 3차 고위급 회담. 2008년 9월 2 4일, 가나. 아크라 발표자료. Effective AID by 2010? What it will take.

\section{4. 제약 요인 및 리스크}

탄자니아는 정치적 안정과 경제개혁을 이루고 있지만, 앞으로 국가 차원의 내부적 위험과 외부 환 경적 위험에 의해 정치 및 경제 안정이 타격을 받을 가능성이 크다.

탄자니아는 2001년, 2005년 IMF, 세계은행, G-8등에 의해 두 차례나 부채탕감을 받았으나, 탄 자니아의 외채는 크게 줄어들지 않았으며 2006년 기준 외채는 79억 달러에 달하고 있다. 고채무의 가장 큰 원인으로 높은 원조의존도를 들 수 있는데, 탄자니아는 정부수입의 41\%(2005/2006 회계 
연도 기준)을 해외원조에 의존할 만큼 원조의존도가 높은 국가이다. 또한, 최근 정부에 대한 재정지 원(Budget Support) 원조가 증가하고 있는데 원조 운영의 효율성과 투명성을 모니터링 할 수 있는 적절한 수단이 아직 미흡한 것도 위험요인으로 지목된다.

외부적 환경을 보면, 최근 세계 경제가 악화되고 있는바, 향후 선진국의 원조 감소가 우려되며 탄자 니아 정부예산 상당 부분이 해외원조에 의존하는 만큼 선진국 원조가 감소할 경우 정부지출 감소와 각종 개발사업에 차질이 불가피하게 된다.

\section{II. 평가 대상}

\section{1. 국별지원전략(CAS)}

KOICA 탄자니아 국별지원전략(Tanzania Country Assistance Strategy)은 2008년에서 2010까 지 3년간 중기지원전략 및 프로그램을 설정하였다. 2006년 아프리카 개발을 위한 한국 이니셔티 브 추진전략에 따라 개발 잠재력이 우수한 탄자니아를 중점협력국가 및 동아프리카 거점국가로 선 정하였다. 이에 따라 협력 사업을 대폭 확대하면서 체계적 전략마련의 필요성이 대두되어 탄자니아 현지사무소에서 초안을 작성하고 외교부가 이를 검토, 최종안을 확정하였다.

중점지원 분야로 ‘농촌개발, 보건의료, 교육, 공공행정’ 분야를 설정하였다. 이는 적은 원조규모로 도 타 원조공여국과의 차별성을 높이고, 우리 원조의 가시성을 높임과 동시에 우리만의 비교우위분 야를 선정하여 집중적으로 지원하는 계획에 따른 것이다.

지역별로는 경제개발 중심지인 다레살람 및 동부 수도권은 $\mathrm{ICT}$, 농업중심지인 도도마, 모로고로 등 중부지역 및 잔지바르는 농촌개발, 북부 및 남부는 교육 중심지로 향후 교육 역량강화 및 기초보건 사업 위주로 지원한다.

\section{2. 사업수행체계}

\section{1) 본부 내 사업수행체계}

$\mathrm{KOICA}$ 의 대 탄자니아 사업은 정책기획팀이 거시적인 무상원조 정책 기획 및 전략을 수립하고, 아 프리카 지역을 총괄하는 지역2팀이 국가계획 수립, 사업발굴 및 계획 수립, 조정, 다자간 협력을 담 당하였다. 예산 편성, 운용 및 관리는 기획예산팀이 담당하며, 예산은 외교부로부터 사업단위 및 부 
서별로 배분받았다.

프로젝트 사업을 중심으로 단계별 연관되는 부서를 살펴보면, 사업발굴 후 현장사무소에서 본부 쪽 으로 사업요청서를 전달하면 지역2팀 ${ }^{4)}$ 에서 1차 검토 후, 사업팀 ${ }^{5)}$ 에 사업검토의견을 요청하였다. 지역 2 팀은 사업팀의 검토의견과 현장사무소, 공관의 의견을 고려하여 2 차 검토를 한 후 사업팀에 타당성 조사를 요청하고 사업수행의 사무소, 공관, 사업부서 등의 의견을 고려하여 해당사업에 대 한 타당성 검토 여부를 최종 판단한다.

사업팀은 다음 연도 사업으로 채택된 사업에 대한 사전심사를 수행하고, 현지사무소와의 협력 하에 사업협의, R/D(Record of Discussions) 체결, 정부 간 합의, 사업 수행 및 모니터링을 추진한다. ${ }^{6}$

모니터링의 경우, 실질적으로 사업수행기관(PMC 업체)이 현지사무소의 감독하에 수행하고, 과중 한 업무량 등의 제약으로 본부 사업팀 담당자가 모니터링을 위해 현지출장을 가는 경우는 극히 제 한적이다.

연수사업부 내 연수기획팀에서는 연수기획 및 국별연수 중장기 계획 수립, 연수사업1팀은 사회개발 분야 분야, 연수사업 2 팀은 경제개발분야의 연수과정을 운영하며 연수운영팀은 연수센터 운영 등을 담당한다.

봉사사업부 내에서는 봉사사업 3팀이 아프리카 지역 단원 관리 및 귀국 단원 사후관리를 담당하고 봉사기획팀은 사업계획 수립 및 예산, 파견협정, 민간단체 해외봉사단 파견사업 지원, 관리 평가 등 을 담당한다.

\section{2) 본부 부서 및 사무소간 업무분담}

현지사무소에서는 본부와의 협력하에 사업발굴, 수원국 정부와의 협의, 사업수행, 모니터링, 현지 봉사단 관리, $\mathrm{NGO}$ 지원 및 협력 등을 수행한다. 수원국과 사업발굴 ${ }^{7)}$ 협의 후, 사업요청서를 본부

4) 지역2팀 내 탄자니아 담당자는 탄자니아를 포함, 짐바브웨, 잠비아, 마다가스카르 등 총 8 개국(겸임국 제외)을 담당하고 있음.

5) 사업팀은 교육팀, 보건의료팀, 환경여성팀, 인도적지원팀, 행정제도팀, 정보통신팀, 농어촌개발팀, 산업에너지 팀의 총 8 개 팀으로 이루어짐.

6) 사업의 타당성검토, 심사 및 사업예비 선정 등은 사업부서에서 주도하되, 지역2팀에서는 예산 등 제반 상황을 고려하여 개 별사업간 우선순위를 조정함.

7) 사업발굴은 수원국 측 요청을 받아서 추진하거나, 현지사무소에서 집중지원부문 내 수요가 있는 관련 부처를 직접 컨택, 적극적으로 발굴하는 2가지 경우가 있음. 
에 보낼 때 사무소 측 의견을 전달하고 이에 대한 최종 사업의 선정 및 결정은 본부 측에서 이루어 진다.

현재 탄자니아사무소에는 사무소장 1 인, 부소장 1인, 행정요원 2 인 등 총 4 명의 KOICA 직원과 3 명의 현지직원이 있어, 현지직원의 경우 주로 행정 및 지원 업무를 담당한다. 각 프로젝트에 대한 모니터링도 사실상 전담하고 있으며, 그밖에 연수생, 물자지원 등의 업무도 함께 추진하고 있다.

사업 추진에 대한 결정권, 예산상 변동에 대해서는 현지사무소의 의사결정권이 상당히 제한적이며, 환율 변동이나 사양변동으로 인한 소규모의 예산 변동에 대해서도 모두 본부의 승인 절차를 거쳐야 한다.

\section{〈그림 2〉 프로젝트 단계별 본부-현지사무소 역할분담}

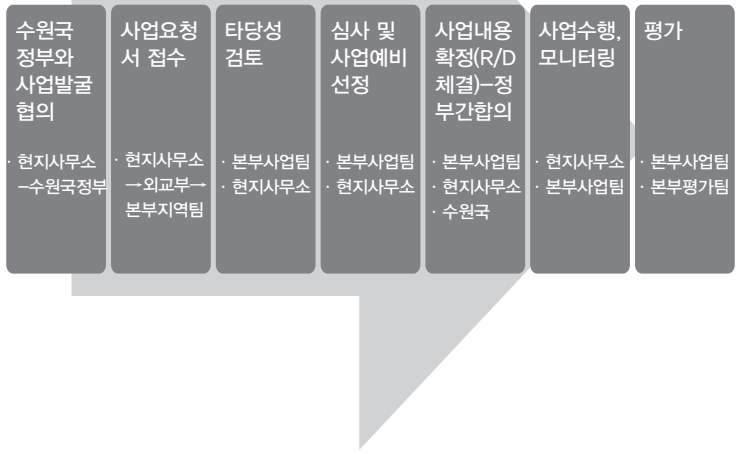

자료: KOICA website 정보 및 관련자 인터뷰 참고.

\section{3. 지원사업}

1992년 한국이 탄자니아와 외교관계를 수립하면서, 주로 단발적인 물자지원으로 무상원조를 제공 하기 시작한 이후, 2005년 현지사무소가 생기면서 지원규모가 200만 달러 이상으로 증가하였다. 2006년 다레살람 공대 ICT 프로젝트를 시작으로 봉사단 · 전문가 파견 및 초청연수 등 기술협력과 연계한 프로젝트 위주 사업을 본격적으로 추진해 왔다. 


\begin{tabular}{c|c|c|c}
\hline 연도 & 지원규모 & 연도 & 지원규모 \\
\hline 1992 & 36 & 2000 & 26 \\
\hline 1993 & 29 & 2001 & 24 \\
\hline 1994 & 31 & 2002 & 56 \\
\hline 1995 & 41 & 2003 & 64 \\
\hline 1996 & 49 & 2004 & 116 \\
\hline 1997 & 49 & 2005 & 227 \\
\hline 1998 & 48 & 2006 & 975 \\
\hline 1999 & 20 & 2007 & 468 \\
\hline
\end{tabular}

자료 : KOICA database.

\section{1) 사업형태별 지원내역}

프로젝트 사업은 다레살람 공대 ICT 교육사업, 도도마 - 신양가 식수개발사업 등과 함께 2006년부 터 본격화된 이후, 2007년 잔지바르 관개시설 재건 및 농업기계화 사업, 2008년 다레살람시 보건 소 진단능력 강화 사업, 농산물 가공훈련센터 건립 및 기술지원 사업이 추진되고 있다. 수원국 정 부 공식 요청사업으로 논의되고 있는 사업으로 루피지 유역 종합수자원개발사업, 전자정부 능력개 발지원, 공무원 리더십교육원, 아루샤 기술대학 ICT 공과설립 지원사업, 잔지바르 도축시설 현대화 사업 등이 사업성 검토 혹은 사전조사 실행 단계에 있다.

봉사단 파견은 2001년 시작된 이후, 2007년 기준 물리치료, 체육교육, 태권도, 의료, 세라믹, 유아 교육, 임업, 기계, 봉제, 컴퓨터, 건축공학, 간호, 과학교육 등 분야에 총 18 분야 46 명을 파견하였 다. 전문가 파견은 1993 년부터 태권도 사범 및 농장관리, 농업정책, 산업개발, 소프트웨어 등 매해 $1 \sim 2$ 명의 전문가를 파견했다.

연수생 초청은 1992년 이후 2007년 현재 전자정부, 직업훈련교수 기술향상, 고위급 지방행정, 농 업개발, 환경영향 평가 등 22 개 과정에 총 54 명의 연수생을 초청하였다.

$\mathrm{NGO}$ 지원은 1995 년 국제기아대책기구의 농업개발사업에 53만 달러를 지원한 이후 굿네이버스와 한국국제기아대책기구 2 개 기관을 지원하였다.

\section{2) 사업분야별 지원 내역}

(1) 교육 
탄자니아는 $12.9 \%$ 의 높은 실업률과 전문기술을 가진 노동력의 부족으로, 농업, IT, 사회 개발 등 인재육성 측면의 어려움을 겪고 있으며, 높은 문맹률· 저수입 · IT 서비스 공급의 부족으로 ICT 기 반이 매우 취약하다.

CAS는 ICT 센터, 대학교 등에 ICT 교육기반 구축을 지원하여 정보화 사회를 주도할 핵심인력 양 성을 지원하겠다고 부문별 목표를 명시한바, 2006년부터 다레살람 공과대학 ICT 교육 강화사업 프 로젝트를 추진하고 있다.

연수생 초청에 있어서도 컴퓨터 응용기술, 아프리카 E-business와 무역실무, 정보통신정책, 행정 정보화 관리, 특허행정 정보화, 정보통신 산업육성, 소프트웨어 등 다양한 IT 관련 과정이 추진되고 있으며, 컴퓨터 관련 총 31 명 봉사단이 파견되었다.

(2) 농촌개발

$\mathrm{NSGRP}$ 의 4번째 목표로 농촌지역 소득증대를 포함, 농촌빈민 감소와 농업생산성 증대 등을 국가 발전의 필수요건으로 명시한바, $\mathrm{CAS}$ 는 농기계 현대화 및 관개개발사업 추진 등을 통한 농촌개발 및 소득증대 지원을 지원목표로 한다.

현재 탄자니아의 농업 생산 중심지인 중부지역 모로고로와 잔지바르 지역에서 농업기계화 및 관개 시설 재건 프로젝트를 추진하고 있으며, 농산물 가공훈련센터 건립 및 기술지원 사업(다레살람 · 모 로고로, 잔지바르) 역시 준비 중이다. 프로젝트 사업과 함께 농업발전정책, 관개개발과 농업용수관 리, 새마을 운동, 농업용수 관련 연수생 초청, 농업정책 - 농장관리, 농업관리 분야의 전문가파견, 채소재배 · 원예 · 작물생산 관련 봉사단 파견 등 다양한 사업형태를 통해 농촌개발을 지원하고 있다.

(3) 보건의료

$\mathrm{NSGRP}$ 에 명시된 깨끗한 물, 환경에의 접근성 강화 목표에 따라, CAS는 식수개발사업을 중점지원 분야로 선정하였다.

현재 1 개 식수개발 프로젝트인 도도마, 신양가 식수개발사업이 진행되고 있으며 최근 모니터링이 진행되고 있다. 제2차 타당성 조사가 완료된 다레살람 보건소 진단능력 강화 프로젝트, 탄자니아 정부 측의 요청으로 사업타당성 검토단계의 루피지 강 유역 종합 수자원 개발사업 등이 있다. 또한, 프로젝트 사업과 함께 의료기기, 의약품 등의 물자지원, 보건의료정책, 지하수자원 개발, 수자원관 
리 관련 연수생 초청, 전문가 파견 및 봉사단 파견도 이루어지고 있다.

(4) 거버넌스

NSGRP에서는 거버넌스와 책임성 제고 관련, 투명하고 공정한 거버넌스 서비스 제공을 강조하였 으며, 이를 근거로 $\mathrm{CAS}$ 역시 전자 정부 역량개발 사업 등 거버넌스 확충을 위한 거버넌스 분야로의 지원확대의 중요성을 명시하고 있다.

이에 행정, 경제기획, 산업정책, 무역, 통신, 농촌개발, 보건, 교육 등 제반 분야의 개발경험 전수를 통한 거버넌스능력 배양을 지원하기 위해 국별 연수프로그램을 적극적으로 활용하고 있으며 프로 젝트 사업으로는 전자정부 능력개발지원, 공무원리더십 교육원 등이 수원국 정부 공식 요청사업으 로 논의 단계이다.

\section{III. 국별지원사업 평가}

\section{1. 국별지원전략(CAS) 평가 ${ }^{8)}$}

\section{1) 계획의 타당성}

(1) 수원국의 개발수요 및 정책과의 연관성

탄자니아의 빈곤감소전략(NSGRP)에서 나타난 탄자니아의 주요 개발수요 분야는 식량증대, 교육, 보건 · 의료, 거버넌스 역량강화, 인프라 등이다. 이러한 탄자니아의 개발수요에 맞추어 $\mathrm{KOICA}$ 의 중점지원분야(priority sector)는 농업개발, 교육, 보건 - 의료, 공공행정 등에 비교적 잘 설정되어 있다. 집중지원 분야 전략은 실제 사업수행에도 전반적으로 반영되어 교육, 보건의료 및 농촌개발 분야에 대한 지원이 전체무상원조액의 $60 \%$ 이상을 차지하고 있지만, 거버넌스의 경우에는 사업 대 부분이 아직 논의단계이다. 따라서 지원분야에 있어서는 수원국의 수요 및 정책에의 연관성이 높다 고 판단된다.

(2) 우리나라 원조정책과의 연관성

우리나라는 아프리카 빈곤퇴치를 위한 국제사회의 노력에 동참하기 위해 2005년 '아프리카개발을 위한 한국 이니셔티브’를 발표하였고, 이에 따라 아프리카 국가 중 18 개국을 협력대상국으로 선정

8) CAS 평가는 앞에서 언급한대로 계획의 타당성, 집행의 효율성, 성과의 유효성을 각각 평가기준으로 함. 
하여 집중지원을 하고 있다. $\mathrm{KOICA}$ 무상원조 전략에 따르면 최빈국이 집중되어 있는 사하라이남 아프리카의 경우, 식수개발 등 보건, 교육, 농촌개발 분야를 집중적으로 지원함으로써 지역 내 빈곤 퇴치와 $\mathrm{MDGS}$ 목표 달성에 기여하고자 하는바, CAS에 명시된 대 탄자니아 중점지원분야 역시 이 와 일치한다.

(3) 국별지원 목표·측정지표 설정 여부 및 타당성

CAS는 대 탄자니아 지원의 최종적인 원조목적(Overall Goal)으로 탄자니아 정부의 Vision 2025 와 NSGRP에 따른 경제성장 및 빈곤감소의 지원으로 설정하였고, 이는 수원국의 개발수요와 정책 에 타당한 목표이다. 그러나 최종적인 개발목적과 세부지원목표의 달성 및 이행 성과를 파악하기 위한 측정지표가 구체적으로 설정되지 않았고, 개별 프로젝트 및 사업이 최종 개발목적, 세부목표 에 어떻게 기여하는지 여부를 측정할 수 있는 지표가 부재한 상황이다.

또한, 개별 프로젝트, 사업 목표의 달성이 CAS 상에 명시된 탄자니아 국가 전체에 대한 지원목표 달성에 어떻게 연결되는지 수직적 연계체제가 미비하다. 그리고 $\mathrm{KOICA}$ 개별사업의 목표는 $\mathrm{CAS}$ 상 목표 및 세부목표에 부합되지만, 개별사업의 목표가 세부목표에 어떻게 기여하였는지 파악할 수 있는 연결고리도 부족하다.

재원배분 측면에 있어서는, 연도별 계획 및 목표치, 측정지표가 구체적으로 설정되지 않았고 이에 대해 수원국 측과의 정보공유가 충분하지 않다. 현재 $\mathrm{KOICA}$ 무상원조는 최종 원조 목표에 따른 지 역별, 국별 재원배분 계획을 세우는 것이 아니라, 개별 발굴 사업에 대한 지원계획 및 부문별 계획 에 따라 특정 수원국에 대한 연간 원조규모 · 재원배분 계획이 설정되고 있어, 수원국 측면에서 중 장기적 원조예측성이 부족하다.

(4) 국별지원전략 수립의 적절성

국별지원전략 수립 과정에 있어서 현지사무소를 중심으로 시행기관인 $\mathrm{KOICA}$ 의 적극적인 역할은 바람직하나, 수원국 정부 및 다른 공여국 - 기관과의 정책 대화, 관련 부처와의 협의가 부족했던 것 으로 판단된다. 특히 관련 부처와의 협의의 경우, 무상원조 주관기관인 외교부를 중심으로 한 정책 적 일관성 제고(policy coherence)를 위해 환경, 여성, 정보통신 등 cross-cutting 주제에 대한 범 정부적 접근(whole of government)을 강화하는 것이 바람직할 것이다. ${ }^{9)}$ 또한, 아프리카 및 탄자

9) $\mathrm{OECD/DAC}$ 은 여러 회원국에 대한 동료평가(Peer Review)에서 cross-cutting 이슈 등에 대한 범정부적 접근과 이를 통한 정책일관성 제고를 강조하고 있음. 
니아 진출에 관심 있는 민간기업, 시민사회의 의견수렴 및 참여 역시 충분하지 않았다.

(5) 국별지원계획 수립시 고려사항 분석여부

CAS에서는 향후 위험요소 및 제약사항에 대해 매우 간략하게 명시하고 있어, 국내외 환경 변화로 발생할 수 있는 예측 가능한 리스크 분석과 이에 대한 대응방안이 추가되는 것이 바람직 할 것으로 보이며, 탄자니아 내 재무부로 대표되는 중앙정부와 다른 정부부처, 지방정부, 그리고 민간기업, 시 민사회 등 다양한 입장의 이해관계자(stakeholder)에 대한 분석과 그들과의 협력방안에 대한 분석 도 필요한 것으로 보인다.

$\mathrm{CAS}$ 에는 거버넌스 외에는 여성, 환경, 소외계층에 대한 고려가 구체적으로 명시되어 있지 않으며, 여성, 환경 등의 주제를 국별지원 시 어떻게 주류화(mainstream)할 수 있는지에 대한 전략적 방향 이 제시되는 것이 바람직할 것으로 보인다.

\section{2) 집행의 효율성}

탄자니아 정부는 교육, 보건, 법률, 지방정부 개혁, 공공재정 관리, 빈곤 모니터링 등 정부재정이 충분히 미치지 않는 분야에 대해서는 여러 공여국이 공동으로 Basket Fund를 운영하도록 권장하 고 있다. 그러나 우리나라의 현재 무상원조 사업방식은 탄자니아 정부가 권고하는 방식과 다른 점 이 많다.

예산배분 측면에 있어서, 프로젝트 - 사업별로 예산을 매년 책정하는 $\mathrm{KOICA}$ 의 시스템은 탄자니아 정부의 예산 및 재정시스템에 조응하지 않고 있다. 이는 국별지원의 최종 개발목적과 세부 전략적 목표 달성을 위한 측정지표가 마련되지 않았기 때문에 목표달성 여부에 대한 모니터링 자체가 불가 능하다.

CAS 목표 달성을 위한 개별사업 목표의 연계성 측면에서는, 전반적인 방향성은 일치하는 것으로 판단되나, 농촌개발 등 일부 분야에 사업이 치중되어 있어 각 지원목표에 대한 균형있는 지원이 이 루어져야 할 것이다. 


\section{〈표 4〉CAS상 목표 및 KOICA 개별사업목표 비교}

\begin{tabular}{|c|c|c|}
\hline CAS상 목표 & 세부목표 & KOICA 사업 목표 \\
\hline \multirow{3}{*}{$\begin{array}{l}\text { Cluster 1. 개발및 빈곤감소 } \\
\text { · 건전경제관리 } \\
\text { · 지속가능하고 광범위한 발전 } \\
\text { · 식량자급율 개선 } \\
\text { · 농촌지역 소득증대 } \\
\text { · 도시지역 소득증대 } \\
\text { · 안정적 에너지 공급 }\end{array}$} & $\begin{array}{l}\text { 농기계 현대화 및 관개개발사업 추 } \\
\text { 진, 기타 농업개발전략 수립 지원 } \\
\text { 등 농촌개발 및 소득증대 지원 }\end{array}$ & $\begin{array}{l}\text { [잔지바르 관개시설 재건, 모로고로 농 } \\
\text { 업기계화 사업] } \\
\cdot \text { 수혜지역 주민 소득증대 }\end{array}$ \\
\hline & \multirow{2}{*}{$\begin{array}{l}\text { 경제개발, 사업개발 등 각종개발전 } \\
\text { 략 수립 및 중소기업 육성, 수출진 } \\
\text { 흥 과정 지원 }\end{array}$} & $\begin{array}{l}\text { [다레살람,모로고로 농산물가공훈련센터 } \\
\text { 건립,기술지원] } \\
\text { · 농산물 가공처리 능력배양 통한 소득 } \\
\text { 증대및 중소기업 육성지원 }\end{array}$ \\
\hline & & $\begin{array}{l}\text { [잔지바르농산물가공훈련센터 건립,기술 } \\
\text { 지원] } \\
\text { · 농산물 가공처리 능력배양 통한 소득 } \\
\text { 증대및 중소기업 육성지원 }\end{array}$ \\
\hline \multirow{3}{*}{$\begin{array}{l}\text { Cluster 2. 인적자원개발/사회복지 } \\
\cdot \text { 초중등교육 향상, 고등/기술직 } \\
\text { 업훈련 확대 } \\
\cdot \text { 모자보건 개선 } \\
\text { · 깨긋한 물, 환경에 대한 접근성 } \\
\text { 강화 } \\
\text { · 소외계층의 사회적 권리보호 } \\
\text { · 공공서비스강화 }\end{array}$} & $\begin{array}{l}\text {. 안정적이고 깨끗한 식수개발 및 기 } \\
\text { 본위생사업 실시 }\end{array}$ & $\begin{array}{l}\text { [도도마, 신양가 식수개발] } \\
\text { · 수혜지역주민의 안전한 식수접근율 향상 } \\
\text { [루피지강 유역 종합수자원 개발]* } \\
\text { : 사업타당성검토 단계 } \\
\text { · 수자원개발계획 수립을 통한 안정적 } \\
\text { 용수/전기공급으로 경제발전에 기여. }\end{array}$ \\
\hline & $\begin{array}{l}\text { 기초 의료보건서비스 제공, 의료보 } \\
\text { 건 제도개선 및 인프라 구축을 통 } \\
\text { 한 주재국 보건목표 달성지원 }\end{array}$ & $\begin{array}{l}\text { [다레살람지역보건소 진단능력강화]** } \\
\cdot \text { 지역보건소 전염병 진단능력, 관리기 } \\
\text { 능 향상, 모자보건시설 및 장비보강을 } \\
\text { 통한 지역주민 건강수준 향상 } \\
\text { : 2차 타당성조사 완료 }\end{array}$ \\
\hline & $\begin{array}{l}\text { 기초교육 역량강화, 교육시스템개 } \\
\text { 선, 직업교육 확대등을 통한 주재 } \\
\text { 국 인적자원개발 인프라 구축지원 }\end{array}$ & \multirow{2}{*}{$\begin{array}{l}\text { [다레살람공대 ICT교육강화] } \\
\text { · ICT 훈련센터보수를 통한 ICT교육부문 } \\
\text { 역량강화 }\end{array}$} \\
\hline \multirow{3}{*}{$\begin{array}{l}\text { Cluster 3. 제도개선/역량강화 } \\
\text { · 민주전, 참여적법치주의 및 거버넌스 } \\
\text { · 부패방지를 통한적절한 재원할당 } \\
\text { · 효과적 공공서비스제공 } \\
\text { · 인권보호 } \\
\text { · 정치, 사회적 단절감소 } \\
\text { · 신변안전 강화, 범죄감소, 성희 } \\
\text { 롱 및 폭력근절 } \\
\text { · 탄자니아 문화홍보 }\end{array}$} & $\begin{array}{l}\text { 첨단 기술혁신 및 ICT 정책수립 및 } \\
\text { IT 산업 육성지원 }\end{array}$ & \\
\hline & $\begin{array}{l}\text { 경제,산업개발 정책수립 분야 및 투 } \\
\text { 장치, 수출증진 분야 중점지원 }\end{array}$ & - \\
\hline & $\begin{array}{l}\text { 중앙정부 및 지방정부 공무원 행정 } \\
\text { 능력배양 지원 }\end{array}$ & - \\
\hline
\end{tabular}

자료: NSGRP, CAS, 개별사업 보고서 참조.

*2008년 10월 기준 루피지강 유역 종합수자원개발은 아직 사업타당성 검토단계

**다레살람지역보건소 진단능력강화는 2차타당성조사를 완료한 단계임.

\section{3) 성과의 유효성}

위험관리 측면에서 $\mathrm{CAS}$ 의 지속가능성을 보면, 현 $\mathrm{CAS}$ 에는 지원상 제약 및 외부적, 국가적, 프로 그램 수준에서의 위험성 분석의 중요성은 명시되어 있으나, 세부적인 내용 및 향후 대응계획이 부 
족하다. $\mathrm{KOICA}$ 를 포함한 우리나라 원조 수행 역시 독자적인 방식으로 추진되고 있어 탄자니아 정 부 및 다른 공여국으로부터 JAST, DPG 체제에 합류하라는 압력이 가중되고 있다. 따라서 향후 우 리나라 원조수행체제를 자세히 검토하고 국제사회의 동향에 단계적으로 맞춰나갈 수 있는 원조수 행체제 변경 전략 수립 및 변화가 필요할 것이다.

\section{2. 사업수행체계 평가}

\section{1) CAS 추진을 위한 사업수행체계 적절성}

지역별 편제가 아닌 지역별, 섹터별 이원화 구조의 이유로 현재 $\mathrm{KOICA}$ 의 사업수행체계는 $\mathrm{CAS}$ 를 기반으로 한 국별 사업추진에는 어려움이 많다. 지역팀의 경우 아프리카 지역을 담당하기는 하나, 국별계획 및 이에 따른 시행, 추진을 총괄하기에는 규모가 제한적이다.

예산배분 상에도 지역별, 국별 사업추진에 어려움이 있어, 현재 $\mathrm{KOICA}$ 는 외교부로부터의 원조형 태별(연수사업, 봉사단 사업, 프로젝트 사업)로 예산을 배분받고, 이는 다시 부서별 ${ }^{10)}$ 로 매년 배분 되고 있다. 원조계획 역시 예산배분의 흐름에 따라 개별 프로젝트, 연수사업, 봉사단 사업별로 각각 별도로 세워지고 있어 CAS와의 연계성이 저하될 수밖에 없는 구조적 문제점이 있다.

\section{2) 업무분담 적절성}

사업부서와 지역부서가 이원화되어 기획과 집행기능이 분리되어 있어 사업관리의 비효율성이 발생 하고, 현지사무소의 경우 사업부서와 조직부서에 이원화된 의사소통을 해야 하는 상황으로 부서 간 의 연계성이 낮다.

현지사무소의 경우 사업발굴, 중점추진분야 선정 등에서는 어느 정도 재량권이 보장되어 있으나, 사업선정, 예산변동에 대해서는 의사결정권이 제한되어 있다. 환율변동, 환경변화로 인한 소규모의 예산변동에 대해서도 모두 본부 승인을 거치는 구조로 이는 변동이 심한 수원국 상황에 대해 신속 하고 유연한 대응에 대한 저해 요소이다. 현재 KOICA 현지사무소는 타 공여기관에 비해 지나치게 인력이 부족하고 개별 프로젝트 수가 지나치게 많으며 봉사단원 관리에 업무의 $50 \%$ 이상을 지원해 야하는 상황으로 제한된 인원에, 역량마저 분산될 수 밖에 없는 구조이다.

\section{3) 현지 조달 - 재정관리 시스템에 대한 일치}

10) 부서편제 역시 원조 형태별로 구분되어 있음. 
조달과 관련하여, 현지 조달 시스템 활용도에 따른 수원국 체제에 대한 일치는 매우 낮은 것으로 파 악된다. 조달 방법에 있어서 $\mathrm{KOICA}$ 는 탄자니아에서 주로 한국 업체와 현지 업체를 대상으로 하는 제한경쟁입찰을 통한 부분 타이드 방식을 주로 활용하며, 탄자니아 정부는 적극적인 언타이드 방식 채택을 요청하고 있다. ${ }^{11)}$ 그러나 현장에서 현지조달가이드라인 및 법규에 대한 이해도 및 활용의지 는 매우 적극적이라는 수혜기관 측 평가를 받고 있다.

수원국 재정관리시스템에 대한 일치도 역시 미흡하여, Exchequer System을 통해 공여국으로부터 받은 원조자금을 각 부문에 배분하는 탄자니아 정부의 시스템을 활용하지 않고, $\mathrm{KOICA}$ 는 개별 프 로젝트별 재원 관리를 직접하고 있다.

\section{4) 공여국 · 수원국과의 조화}

탄자니아 내 DAC 회원국과 수원국은 JAST에 따른 DPG 메커니즘을 통해 모든 협력 및 논의의 장 을 일원화하고 있으나, 한국 정부는 이에 참여하지 않고 있다. $\mathrm{DPG}$ 회의를 중심으로 이루어지는 Cluster별 · 부문별 목표 달성을 위한 수원국 내 메커니즘과는 별도로 개별 프로젝트를 시행하고 있 어, 타 공여국 및 수원국과의 협력과 조정은 상당히 미흡한 상황이다.

협동조사(joint analysis), 협동조사단(joint mission) 등을 통한 조화에의 기여도 역시 부족한 상 황이다. 탄자니아 정부는 지나치게 많은 공여국 관리과 분산된 경로를 통해 협의하고 공여국의 출 장단 등에 협조하는데 지나치게 많은 시간을 소요하여 협동 조사, 협동 조사단 등을 강력히 권고함 하고 있다.

\section{3. 지원사업 평가}

\section{1) 연관성}

$\mathrm{KOICA}$ 의 대 탄자니아 사업은 전반적으로 해당 국가의 빈곤퇴치전략, 개발수요에 대한 연관성은 높다고 평가된다. MDG 및 NSGRP상에 나타난 교육 및 ICT, 농업개발, 보건·의료 등의 부문에 대한 수원국의 수요를 적절히 반영하고 있으며 사업들은 수원국 개발수요에 대한 부합 정도가 매우 높은 편이다. 그러나 적은 원조규모에 비해 지나치게 많은 부문에 사업이 분산되어 있다는 지적이 많다. 그리고 대부분의 KOICA 프로젝트의 경우 규모가 크지 않기 때문에 탄자니아 내 개발수요가

11) 2008 파리선언 모니터링 보고서에 의하면 탄자니아 내 원조 중 $99 \%$ 가 언타이드였고, 이는 주로 GBS와 basket fund를 통한 원조 증가의 결과임. 최근 마련한 원조 언타이드화 로드맵(안)에 따라 2010년 DAC가입까지 단계적인 원조 언타이 드 추진과 함께 한국 산업, 컨설팅 업계의 역량강화를 위한 제도적 지원이 시급함. 
높은 부문의 개발에 대한 파급 효과가 제한적이다. 또한, 프로젝트 및 사업 각각에 대한 수혜자 측 만족도는 높은 반면, 수원국 주도 프로그램과의 연계, 참여 등은 미흡하다.

\section{2) 효율성}

사업비용 측면에서는 현재 시점에 종료 프로젝트가 없어, 계획 비용대비 실 집행액 측정이 힘들기 때문에 비용 측면에서의 평가는 용이하지 않다. KOICA 프로젝트는 대부분 계획된 금액 내에서 집행 되는 경우가 많은 것으로 판단된다. 이는 사업비용 상승에 따른 예기치 않는 문제가 발생할 수 있다.

\section{3) 효과성}

수원국 측의 만족도 측면에서 2007년 ‘KOICA 무상·기술협력사업 수혜자평가보고서’에 따르면, 탄자니아 측은 특히 교육, 농업 분야에 대한 프로젝트 및 봉사단 · 전문가 파견이 자국의 경제사회 발전에 효과적으로 기여하였다고 평가하고 있다. 수원국 측은 $\mathrm{KOICA}$ 의 방법이 타 공여기관의 사업 에 비해 수원국에 대한 역량개발과 지식전수 및 장기적인 주인의식 제고에 바람직하다는 긍정적인 평가를 하였다. 그러나 이러한 프로젝트식 접근은 부문별 접근(sector wide approaches)에 비교할 때, 개별사업 간 유기적 연계성과 시너지 효과가 부족하다는 한계점이 있다.

현재 탄자니아에서 활동하는 2개의 국내 $\mathrm{NGO}$ (굿네이버스, 기아대책)에 대한 재정지원을 하고 있 다. 제한적 협력의 주된 이유로는 국내에서 사업지원 신청을 하는 $\mathrm{NGO}$ 대부분이 선교목적의 종 교기반 기관으로 아프리카 및 탄자니아에 대한 전문성과 사업역량을 갖춘 경우가 많지 않고, 현지 $\mathrm{NGO}$ 및 국제 $\mathrm{NGO}$ 와의 협력 역시 관리의 어려움, 언어장벽 및 인력 부족 등의 이유로 $\mathrm{NGO}$ 와의 협력은 상당히 제한적이다.

\section{4) 파급효과}

최근 중간평가를 실시한 도도마, 신양가 식수개발 사업의 경우 동 사업을 통한 식수접근율 향상으 로 유휴시간을 활용한 아동 교육기회 확대, 여성사회 참여율 증가에 대한 기여 등의 긍정적 파급 효 과가 있을 것으로 예상된다. 안정적인 식수공급을 통한 주민 생활 개선, 소득증대 등 경제적 효과, 수인성 질병 예방을 통한 보건위생환경 개선의 사회 - 환경적 효과가 예상된다. 그러나 규모 자체가 크지 않아 탄자니아 전체의 식수개발 부문에 대한 파급 효과는 제한적이라고 추측된다.

훈련생 초청 및 전문가 파견 등의 기술협력 사업의 경우 수혜자 및 수혜기관의 역량개발에 많은 도움을 주었다는 수원국 측의 평가를 받고 있다. 그러나 프로젝트 사업에 있어서 수원국이 아닌 
$\mathrm{KOICA}$ 가 직접 수행, 관리하는 방식은 수혜기관의 역량개발, 제도강화에 기여도가 낮을 수 있으므 로 향후에는 수원국의 참여를 높일 수 있도록 하는 방향을 모색하는 것이 바람직할 것으로 보인다.

\section{5) 지속가능성}

현재 종료 사업이 없는 상황이기 때문에 지속가능성에 대해 단정적인 평가를 하기는 어려우나, 사 업종료 후 재정적, 제도적 측면에서의 지속가능성에 대해 초기 계획 시 좀 더 고민이 필요한 것으로 판단된다. $\mathrm{KOICA}$ 프로젝트 사업의 경우 사업계획, 자금관리를 수원기관이 아닌 $\mathrm{KOICA}$ 가 총괄하 고 있어, 재정지원이나 프로그램 사업을 통해 수원기관이 직접 계획, 자금관리를 주관하는 타 공여 기관의 방법과 차이가 있다. 프로젝트 초기 단계부터 원조 종료 이후 수원국 및 수혜기관이 재정적, 제도적, 인력적 측면에서 중장기적인 자립이 가능하도록 주인의식(ownership)에 바탕을 둔 사업계 획을 세우는 것이 중요하다.

\section{IV. 교훈 및 제언}

\section{1. 원조의 예측가능성 및 상호책임성 강화}

일반적으로 다른 공여국들은 전문가 등 인력 및 예산을 투입하여 장기간에 걸쳐 CAS를 만드는 데 비해 $\mathrm{KOICA}$ 는 짧은 기간에 소수 내부인력으로 어려운 상황 속에서도 $\mathrm{CAS}$ 를 수립하였다는 점은 괄목할 발전이라고 생각된다. 그러나 중장기적으로 탄자니아와 한국의 개발파트너십을 구축하고, $\mathrm{CAS}$ 전략을 강화하기 위해서는 원조의 예측가능성 강화를 통한 보다 효과적인 지원체제 구축이 시 급하다.

탄자니아는 모범 수원국으로서 원조공여국그룹(DPG)에 의한 공동지원전략(JAST)에 의해 국제사 회의 체계적인 지원을 받고 있고, 원조효과성 제고를 위해 수원체제가 강화되고 있다. 그러므로 수 원국 정부와 사전협의 및 정책 대화를 강화하고 그에 따라 CAS를 강화하는 등의 노력이 필요하다.

그리고 원조사업의 효과성과 상호책임성(mutual accountability)이 제고될 수 있도록 제도적 개선 이 이루어져, CAS 수립 및 계획단계에서 이해관계자들의 참여를 통해 참가형 계획(Participatory Planning)을 추진하고, 지원 가능분야와 사업규모의 예측가능성을 강화해야 한다. 또한, CAS가 탄자니아의 통합된 정책안과 예산계획에 조응할 수 있도록 작성되어야 하고, 아울러 다년간 원조프 로그램이 안정적으로 운용될 수 있도록 원조방침과 지원전략이 마련되어야 한다. 


\section{2. 예산배분 및 실시계획 작성}

현재 KOICA가 수행하는 사업들이 2008 2010년 중기전략인 CAS에는 사업방향만 설정되어 있고 중기예산은 명시되어 있지 않고 있으므로 탄자니아 정부가 제시하는 통합된 종합계획안에 조응되 기 위해서는 적정 규모의 예산계획이 마련되어야 한다. 탄자니아는 중점지원국이므로 국별 예산을 지속적으로 확대하고, 탄자니아에 대한 국별지원계획을 3년 주기로 마련하여 원조의 예측가능성을 제고해야 한다.

$\mathrm{CAS}$ 는 정책단계에서 작성된 국별 원조전략으로써 정책 $\rightarrow$ 프로그램 $\rightarrow$ 프로젝트 단계 순으로 추진되 는 $\mathrm{ODA}$ 운영체제를 고려할 때, 실시기관의 기본방침인 '국별 사업실시계획'이 작성되어야 한다. $\mathrm{CAS}$ 에 기반을 두어 국별로 사전 재원배분을 하고, 그에 따라 예측 가능한 원조를 수행하며, 중기예 산, 중점지원분야의 과제별 지침을 포함한 $\mathrm{CAS}$ 기반의 사업실시계획을 연간 국별 세부지원계획에 포함, 구체화하여야 한다. 이를 토대로 예산배정, 지원계획이 구체적으로 제시되어야 할 것이다.

그리고 부문별 전략과 하위 사업 간의 연계성을 강화하고, 각 사업이 부문별 전략목표 달성에 기여 할 수 있도록 측정지표를 설정하여 탄자니아 국별원조전략이 프로그램 중심의 접근(programme based approaches: PBAs) $\rightarrow$ Sector Wide Approach $\rightarrow$ 프로젝트 단계로 연계될 수 있도록 해야 한다. 또한, 국별 사업실시계획에는 시민사회, 민간부문, 그리고 다른 정부부처의 다양한 의견도 수 렴되어야 할 것이다.

〈그림 3 〉 CAS의 실시계획 흐름도

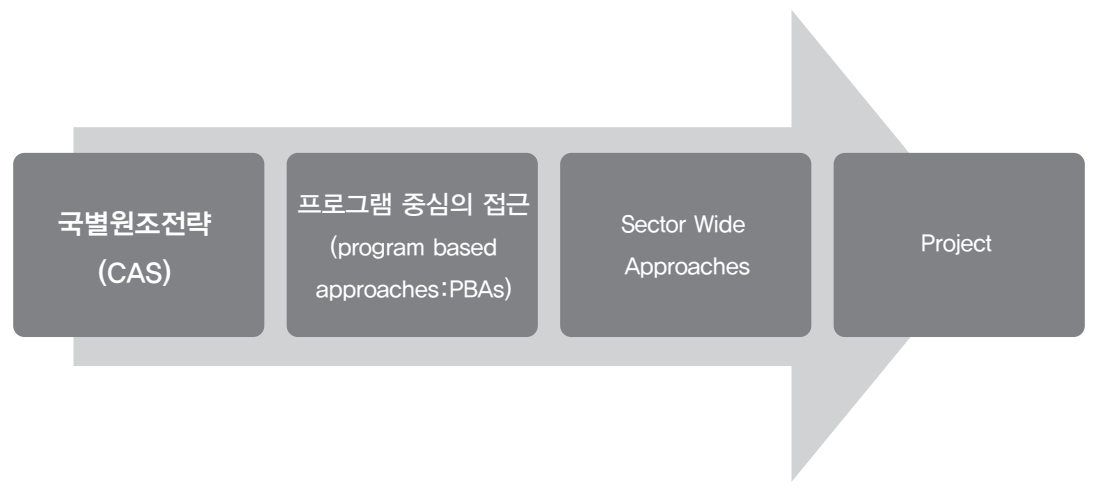

\section{3. 결과중심의 관리체제 강화}

현재 추진되고 있는 프로젝트 위주의 개별적인 산출(output)에서 벗어나 최종적 개발목표에 실제 
로 얼마나 기여했는지 파악할 수 있는 성과(outcome)중심의 관리체제를 강화해야 한다. 우리나라 는 $\mathrm{CAS}$ 를 수립하였음에도 불구하고 탄자니아 국별지원의 전략적, 최종적 목표 달성을 위한 구체적 인 측정 지표를 설정하지 않아, 개별 사업의 결과가 수원국의 개발목표 및 부문별 목표의 달성에 어 떤 파급 효과를 주었는지 파악하기가 어렵다.

따라서 주요 사업에 대해서는 계획 $\rightarrow$ 실시 $\rightarrow$ 평가 사이클에 따라 $\mathrm{PDM}($ Project Design Matrix) 기 반의 운영과 관리 및 부문별 접근(Sector-wide approach)을 강화하고, DPG 그룹을 통한 다른 공 여국과의 협의 및 조정 노력을 제고해야 한다. 이를 위해서는 MDG 및 NSGRP상에 나타난 개발수 요에 따라, 부문별 전략목표에 대한 기여도를 파악할 수 있는 측정지표를 활용하고, 주요 선진 공여 국과 협력 및 조화가 필수적이다. 원조규모가 상대적으로 적은 현실을 감안하여 공여국간 역할 분 담(division of labour) 및 조화를 통해 공동의 성과지표를 설정하고, DPG 회의를 통한 공동 논의 에 적극적인 참여가 필요하다.

\section{4. 원조형태의 다양화}

최근 국제사회의 원조는 원조의 효과성 제고를 위해 전통적인 프로젝트형 원조와 함께 다양한 프로 그램형 원조를 추진하고 있다. ${ }^{12)}$ 탄자니아의 경우에도 소규모 프로젝트식 원조 증가에 따른 거래비 용 증가와 관리체제 약화의 문제점을 극복하고, 원조의 예측가능성을 높이기 위하여 무상자금공여 방식의 빈곤감소재정지원(PRBS)이 활발하게 추진되고 있다. 또한, $\mathrm{PRBS}$ 에 의하여 진행되는 탄자 니아 정부의 행정개혁은 공공재정관리 개혁프로그램(PFMRF), 공공서비스 개혁프로그램(PSRP), 지방행정 개혁프로그램(LGRP) 등 빈곤감소와 경제성장을 달성하기 위한 거시적 개혁으로 성과를 나타내고 있다.

$\mathrm{CIDA}, \mathrm{JICA}$ 등 다른 공여기관 역시 다양한 논의와 고민을 통하여 프로젝트 방식에서 프로그램 방 식으로의 이전을 추진하였다. 캐나다 CIDA의 경우, 1997 2003 탄자니아 국별프로그램에 대한 평 가보고서에서 원조효과성과 조화, 수원국 주인의식 강화, 성과위주 관리를 위해서 프로그램 방식으 로의 이전이 불가피함을 명시하였다. 일본 JICA의 경우 2001년 5.32억 엔을 시작으로 2005년 26 억 엔 규모의 재정지원을 추진함과 함께 현지사무소가 각종 회의에 적극적으로 참여, 수준 높은 정 책논의를 수행할 수 있도록 전문성을 강화하는데 중점적인 노력을 기울이고 있다.

12) 일반적으로 프로그램식 원조는 크게 식량계획지원과 재정계획지원으로 나뉘고, 재정지원계획의 경우 예산지원과 국제수 지지원으로 구분된다. 예산지원은 직접적인 재정지원으로서 일반재정지원(General Budget Support)과 섹터재정지원으 로 나눌 수 있다. 국제수지지원(Balance of Payment Support)은 수입지원과 채무면제로 나눌 수 있다. 
따라서 2010년 DAC 가입에 대비하여 탄자니아 일반재정지원에 $\mathrm{KOICA}$ 도 적극적으로 참여함으로 써 현재의 프로젝트 위주 원조에서 벗어나 프로그램 방식을 적절히 병행하는 방법을 단계적으로 추 진해야 한다. ${ }^{13)}$

\section{5. 중점지원분야의 집중과 선택}

탄자니아 MDG 이행성과 및 NSGRP에 따르면 농업개발, 교육, 보건·의료, 거버넌스, 인프라 등 에 개발수요가 있으며, $\mathrm{CAS}$ 는 이 중 인프라만을 제외한 모든 분야를 중점지원분야로 선정하였는 바, 좀 더 역량을 집중해야할 필요가 있다. 현실적으로 무상원조 규모의 급격한 확대가 힘들고 이미 대부분의 선진공여국이 한국과 중점지원분야가 유사한 상황에서, 최근 강화되는 공여국간 역할분 담 추세를 고려하여 우리의 비교우위가 있는 2 3개 부문에 대해 집중 지원해야할 것이다.

〈표 5〉 공여국 부문별 역할 분담 현황 및 계획

\begin{tabular}{c|c|c|c|c|c}
\hline \multirow{2}{*}{ 연도 } & \multicolumn{5}{|c}{ 참여공화국 · 기관 수 } \\
\cline { 2 - 6 } & 농업 & 교육 & 식수 & 보건 · 의료 & 거버넌스 \\
\hline \hline 2006년 & 13 & 17 & 13 & 17 & - \\
\hline 2008년 & 9 & 11 & 9 & 16 & 11 \\
\hline 2010년 & 8 & 9 & 7 & 15 & 10 \\
\hline
\end{tabular}

자료: World Bank(2008), DPG division of labour in Tanzania

한국의 경우 관개시설 개발 및 쌀을 중심으로 한 품종개발 및 기술전수 등 농업개발의 성공적인 경 험이 좋은 지원 분야가 될 수 있을 것이며, 이는 서구 선진공여국에는 없는 한국만의 비교우위 분야 이다. 현재 lead donor인 $\mathrm{FAO}$ 가 주도하는 $\mathrm{DPG}$ 농업개발 부문 미팅에 보다 적극적으로 참여하여 한국의 경험을 공유할 수 있는 지점에 대해 다른 공여국과의 논의 및 협력이 필요할 것이다.

중점지원 분야에 대한 지원을 강화하기 위해서는 체계적인 조사와 연구가 전제되어야 하며, CAS에 설정된 중점지원분야에 대해서 부문 조사를 체계적으로 추진해 나가야 한다. 특히 탄자니아에 대한 지원이 초기단계이므로 개발조사사업을 보다 강화하고, 각 섹터에 대한 조사를 확대하여 수원국의 구체적인 수요를 파악하고 이를 위한 $\mathrm{KOICA}$ 의 역할을 구체적으로 설정해나가야 할 것이다. 이를 기반으로 전략적인 차원에서 유망원조사업을 발굴하고, 각 부문에 대한 사업을 연계하여 프로그램 화 하는 방안을 모색할 수 있다. 그리고 자금제약으로 초기단계의 경제조사 및 부문조사가 추진하

13) 예산 원조는 수원국의 주인의식을 강화시키고, 공공재정관리(PFM) 시스템을 개선시킴으로써 원조의 예측성 및 거래 비 용 최소화, 수원국의 책임성을 강화시킬 수 있음. 
기 어려울 경우, 한국정부가 AfDB에 설치한 신탁기금(Trust Fund)을 적극 활용할 수도 있다. ${ }^{14)}$

\section{6. 사업수행체제 개편 및 현장중심의 원조체제 강화}

현지사무소의 사업 운영 및 관리 능력 강화를 통해 탄자니아 현지의 요구에 효과적으로 대응할 수 있는 현장중심의 운영체제를 도모할 필요가 있다. 이를 위해 $\mathrm{KOICA}$ 본부에서 현지사무소로 프로젝 트 실행과 관련한 의사결정 권한 이양 등 탈 중앙집권화 작업을 적극적으로 추진해야 한다.

현재 $\mathrm{KOICA}$ 의 사업수행체계는 사업조사, 결과보고, 평가 등을 모두 본부에서 주도적으로 추진하 고, 현지사무소는 주로 지원기능을 담당하는 구조이다. 그러나 현장중심의 원조체제 강화를 위해 서는 사업발굴 및 조사, 결과보고에 대한 사업추진의 권한을 현지사무소에 이양하고, 본부는 사업 결과에 대한 검토 및 평가에 중점을 두는 방식으로 전환해야 한다. 그리고 탄자니아 정부와 무상협 력 기본협정체결을 통해 사무소법인화 및 사업수행의 기본체계 개선방안이 수립되어야 할 것이다.

또한, 현지사무소와의 유기적인 소통 및 국별 재원배분에 따른 예측 가능한 원조수행을 위해, 기획 과 실행이 한 부서에서 일원화 되도록 하고 사무소도 사업부서-지역부서와 각각 의사소통을 하는 어려움을 줄일 수 있도록 본부의 조직개편이 필요하다.

연수 및 봉사사업 관련 업무 추진체계 개선. 현지사무소의 사업관련 행정업무가 다른 공여국에 비 해 지나치게 많아, 사업관리를 위해 역량이 분산되어 사업발굴 및 계획기능이 위축되는 등 효율성 이 크게 저하되고 있다. 현재 $\mathrm{KOICA}$ 현지사무소에는 4명의 본부 인력과 3명의 현지 인력으로 다 양한 프로젝트 사업 및 봉사단 사업 관리 때문에 주기적으로 열리는 $\mathrm{DPG}$ 회의 등에 적극적인 참여 가 현실적으로 어려운 상황이다. 이러한 문제를 해결하기 위해서는 현지인력 확충 및 봉사단 사업 관리체계 개선 ${ }^{15)}$ 등의 전향적 방안을 마련해야 한다.

현지사무소 중심으로 선진공여국 회의 및 JAST에 적극적인 참여가 필요하다. 모범 수원국인 탄자 니아는 DPG 회의를 통해 모든 개발 주제 및 부문별 논의와 협력을 추진하고 있으므로 KOICA는 보 다 활발한 $\mathrm{DPG}$ 미팅 참가를 통해 타 공여국과의 조화 및 정보공유 노력을 강화해야 할 것이다.

14) 2005년 4월 한 - 아프리카 재무장관회의를 계기로 KOAFEC(Korea-Africa Economic Cooperation) 이라는 신탁기금이 도입되어 5 백만 달러 규모의 KOAFEC Trust Fund가 2007년 신규로 설립됨. KOAFEC 신탁기금은 역내 인프라 및 ICT 개 발, 공무원 및 학생들 대상 개발경험전수를 위한 세미나, 워크솝, 교육 - 훈련 등 다양한 협력분야를 대상으로 조사, 타당 성 검토 등에 활용

15) 봉사단현지관리 인력 확충 및 장기적으로는 봉사사업 관리부분의 아웃소싱 등을 통해 사업 계획, 다른 공여국과의 업무 조정 및 조화, 수원국과의 대화 등 보다 핵심적인 업무에 집중할 수 있는 제도적 지원이 선행되어야 할 것임. 
이와 같이 현장중심의 원조실시체제를 강화함으로써 수원국 수요에 적극적으로 대응하고, 국제사 회에서 타 공여국과의 조화 및 협력을 강화하기 위한 노력이 병행되어야 한다. 이를 위해서는 본부 와 사무소 간의 역할분담이 명확하게 설정되어야 하고 사무소의 이니셔티브를 존중하는 사업수행 체제 구축이 전제되어야 한다. 그리고 프로젝트 방식의 사업보다는 일반재정지원, SWAP 등 프로 그램 방식의 원조 추진을 중심으로 한 전략 강화가 필요하다. 또한, 적절한 예산관리 및 직원의 전 문성 강화가 시급하고 선진공여국과 협력을 통해 Joint monitoring, delegated cooperation 등의 방식을 시험적으로 추진해야 할 것이다. 


\section{참고문헌}

\section{1.국내문헌}

권율. 2006.「우리나라 ODA 사업의 효과성 제고방안: 모니터링과 평가체제를 중심으 로」.『국제개발협력』2006년 3호. 한국국제협력단.

권율 외. 2006. 『우리나라 대외원조정책의 선진화방안: 국제개발협력 패러다임의 변화와 한국 $\mathrm{ODA}$ 의 개혁과제』. 대외경제정책연구원.

한국국제협력단. 2007a.『탄자니아 국별지원전략』.

한국국제협력단. 2007b. 『07년 무상/기술협력사업 수혜자평가 보고서』.

한국국제협력단. 2007c. 『탄자니아 관개시설 재건 및 농업기계화 사업: 사전조사 결과 보고서』.

한국국제협력단. $2007 \mathrm{~d}$. ${ }^{\circledR}$ 탄자니아 다레살람 공과대학 ICT 교육강화 사업: 실시협의 결과 보고서』.

한국국제협력단. 2006. 『탄자니아 도도마/신양가 지역 식수개발사업 실시협의 및 르완 다 나바롱고강 식수개발 타당성조사사업 사전조사 결과 보고서』.

한국국제협력단 사단법인 한국해외봉사단원연합회. 2004. 『국별편람: 탄자니아』.

\section{2. 국외문헌}

Asian Development Bank. 2006. Guidelines for the Preparation of Country Assistance Program Evaluation Reports by Operations Evaluation Department. Manila: ADB.

CIDA. 2006. Evaluation of the CIDA Tanzania Program 1997-2003. Quebec: CIDA.

DFID. 2004. Evaluation of DFID Country Programmes, Synthesis Report. London: DFID. 
DFID. 2005. Joint Evaluation of General Budget Support Tanzania 1995-2004. London: DFID.

DFID. 2007. Tanzania Country Assistance Plan. DFID. London

Economic and Social Research Foundation. 2005. Enhancing Aid Relationships in Tanzania: Independent Monitoring Group Report 2005. ESRF. Dar es Salaam

Economic Commission for Africa. 2005. The Millenium Development Goals in Africa: Progress and Challenges. Prepared for the World Summit 2008 in New York by Economic Commission for Africa. New York.

EIU. 2007. Country Report: Tanzania.

EIU. 2008. Country Profile: Tanzania.

Helleiner, Gerald et al. 1995, Report of the Group of Independent Advisers on Development Cooperation Issues between Tanzania and Its Aid Donors. Royal Danish Ministry of Foreign Affairs.

JICA. 2006. Country Assistance Evaluation of Tanzania. Tokyo: JICA.

Ministry of Planning, Economy and Empowerment of Tanzania. 2006. Millennium Development Goals Progress Report for Tanzania. Dar es Salaam.

Ministry of Finance in Tanzania. 2007. General budget Support 2007 Annual review report. Dar es Salaam.

OECD. 2005. “Joint Evaluation of General Budget Support 1994-2004 : Policy questions and answers.". Paris: OECD.

OECD. 2008. “2008 Survey on Monitoring the Paris Declaration, Effective Aid by 2010 What it will take. Tanzania."

OECD. 2008. Accra Action Agenda.

OECD/DAC. 2005. Peer Review - Sweden. OECD. Paris. 
OECD/DAC. 2006a. Peer Review - United Kingdom. Paris: OECD.

OECD/DAC. 2006b. Peer Review - Germany. Paris: OECD.

OECD/DAC. 2006c. Harmonizing Donor Practice for Effective Aid Delivery. Paris: OECD.

Swedish Agency for Development Evaluation. 2007. "What Determines the Choices of Aid Modalities, a framework for assessing incentive structures”. SADEV Report. Karlstad.

United Republic of Tanzania, 2006. Joint Assistance Strategy for Tanzania. Dar es Salaam.

United Republic of Tanzania, 2007. Joint Assistance Strategy for Tanzania, Action Plan and Monitoring Framework. Dar es Salaam.

UN. 2008. Achieving the Millennium Development Goals in Africa. UN Department of Public Information. New York.

World Bank. 2007. Joint Assistance Strategy for the United republic of Tanzania. Report No. 38652-TZ. Washington DC: World Bank.

World Bank.. 2008. "Revised DPG Division of Labour in Tanzania”. Washington DC: World Bank.

World Bank Operations Evaluation Department. 2004. “Monitoring\&Evaluation: Some tools, Methods \& Approaches”. Washington DC: World Bank.

www.tanzania.go.tz

www.mof.go.tz

(Development Partners Group). www.tzdpg.or.tz

http://stats.oecd.org 